\title{
Erratum to: Level of habitual physical activity in children and adolescents from the Region of Murcia (Spain)
}

Guillermo Felipe López Sánchez ${ }^{*}$, Sixto González-Víllora and Arturo Díaz Suárez

\section{Erratum to: SpringerPlus (2016) 5:386 \\ DOI 10.1186/s40064-016-2033-8}

Upon publication, it was noticed that in the original version of the article (López Sánchez et al. 2016), Sixto González-Víllora's name was incorrectly given as Sixto González Víllora. This has now been corrected in this erratum.

\section{Author details}

${ }^{1}$ Faculty of Sports Sciences, University of Murcia, Murcia, Spain. ${ }^{2}$ Teacher Training Faculty of Cuenca, University of Castilla-la Mancha, Cuenca, Spain.

The online version of the original article can be found under doi:10.1186/s40064-016-2033-8.

Received: 27 June 2016 Accepted: 27 June 2016

Published online: 11 July 2016

\section{Reference}

López Sánchez GF, González-Víllora S, Díaz Suárez A (2016) Level of habitual physical activity in children and adolescents from the Region of Murcia (Spain). SpringerPlus 5:386

\footnotetext{
*Correspondence: gfls@um.es

${ }^{1}$ Faculty of Sports Sciences, University of Murcia, Murcia, Spain

Full list of author information is available at the end of the article
} 